\title{
PHYSICAL ENVIRONMENT IN NON-VENTILATED CULTURE VESSELS AFFECTS IN VITRO GROWTH AND MORPHOGENESIS OF SEVERAL GULTIVARS OF DIANTHUS CARYOPHYLLUS L.
}

\author{
M. A. FAL ${ }^{1 *}$, J. P. MAJADA ${ }^{2}$, AND R. SÁNCHEZ TAMÉS ${ }^{1}$ \\ ${ }^{1}$ Lab. Fisiología Vegetal, Dpto. Biología de Organismos y Sistemas, Universidad de Oviedo, C/ Catedrático Rodrigo Uría s/n 33071, \\ Oviedo, Spain \\ ${ }^{2}$ Area de Cultivos Hortofrutícolas y Forestales, SERIDA, Aptdo 13, 33300 Villaviciosa, Asturias, Spain
}

(Received 15 October 2001; accepted 8 May 2002; editor E. E. Benson)

\begin{abstract}
SUMMARY
Differences were shown in the environmental conditions inside four types of non-ventilated culture vessels (glass babyfood jars capped with metal steel or Magenta B-caps, jam glass jars capped with metal steel caps, and Magenta GA7 culture vessels) that were incubated in the same external growth room conditions. Vessel light transmittance varied from $83 \%$ to $53 \%$ and determined the availability of photosynthetic photon flux density (PPFD) for explants. The mean of medium desiccation in the culture period $(30 \mathrm{~d})$ was from $2.8 \mathrm{~g}$ in vessels with the lowest rate of gas exchange $\left(0.02 \mathrm{~h}^{-1}\right)$ to $10.4 \mathrm{~g}$ in vessels with the highest $\left(1.1 \mathrm{~h}^{-1}\right)$. In all cases, the temperature inside the culture vessel increased during the light period and decreased during the dark period, and relative humidity was close to $100 \%$. Results of in vitro growth and morphogenesis of Dianthus caryophyllus L. cvs. Scania, White Sim, Angeline, and Pink Calypso provided evidence that the environmental differences detected inside these four types of non-ventilated culture vessels was sufficient to affect micropropagation, mainly related with the specific sensitivity of each cultivar to the gas exchange and medium desiccation determined by the vessel type.
\end{abstract}

Key words: hyperhydricity; light; medium desiccation; micropropagation; gas exchange; ventilation.

\section{INTRODUCTION}

Poor or no diffusion of gases between the culture vessel and the outside atmosphere is often described as a cause of necrosis, hyperhydricity, and other plant anomalies in vitro (De Proft et al., 1985; Ziv, 1986; McCown and Sellmer, 1987). This has led to the design of new vessels that allow ventilation of the internal atmosphere, specially for culturing species prone to hyperhydricity (Majada et al., 1997, 2000; Fal et al., 1999). However, excess ventilation in the culture vessels can have the unwanted effect of producing fast desiccation of the culture medium and reduction of tissue growth (Walker et al., 1989; Sallanon and Maziere, 1992).

Our previous results (Majada et al., 1997, 2000; Fal et al., 1999) showed differences between some Dianthus caryophyllus L. cultivars in their behavior when cultured in vessels ventilated through porous membrane closures. This ventilation system was adequate for improving micropropagation when hyperhidricity was a problem. Nevertheless, a dilemma seemed to exist between plant quantity and quality in relation to ventilation during culture; plant quality is concurrent with increasing ventilation but, often, this means reduction of plant growth and then in the final number of plants. Since on occasion non-ventilated systems are more appropriate for micropropagation of plants not sensitive to hyperhydricity, the objective of this paper was to study the

\footnotetext{
*Author to whom correspondence should be addressed: Email mafal@
} correo.uniovi.es behavior of $D$. caryophyllus cultivars in relation to the microenvironment in four types of non-ventilated culture vessels traditionally used for plant micropropagation.

The interplay of the culture vessel with the environmental parameters controlled inside the growth chamber finally determine the in vitro explant environment and, therefore, the results obtained in plant micropropagation (Drew et al., 1988; McClelland and Smith, 1990; Smith and McClelland, 1991). So, in order to determine the possible existence of environmental differences between culture vessels even when they were non-ventilated, special attention was paid to the available light, temperature and relative humidity, and the rate of gas exchange and desiccation in the culture vessels assayed.

\section{Materials and Methods}

The culture vessels included glass jam jars, $370 \mathrm{ml}$ in volume, capped with metal steel caps (Fig. 1A); glass baby-food jars, $200 \mathrm{ml}$ in volume, capped with metal steel caps (Fig. $1 B$ ); the same type of glass jars capped with polypropylene Magenta $^{\mathrm{TM}}$ B-caps (Sigma-Aldrich Química S.A., Alcobendas, Spain; Fig. 1C), and Magenta ${ }^{\text {тM }}$ GA7 polycarbonate vessels, $275 \mathrm{ml}$ in volume, capped with polypropylene covers (Sigma-Aldrich Química S.A., Alcobendas, Spain; Fig. 1D).

In vitro-grown shoots of Dianthus caryphyllus L. cvs. Scania, White Sim, Angeline, and Pink Calypso were previously obtained by meristem culture. Apical meristems were aseptically excised from greenhouse-grown plants and cultured on MS basal medium (Murashige and Skoog, 1962) plus $58.6 \mathrm{~m} M$ sucrose, $4.6 \mu M$ kinetin, and $1.7 \mu M$ indoleacetic acid as described by Casares et al. (1987). Single nodal segments were aseptically excised from the in vitro-developed shoots and cultured on the same culture medium 
A

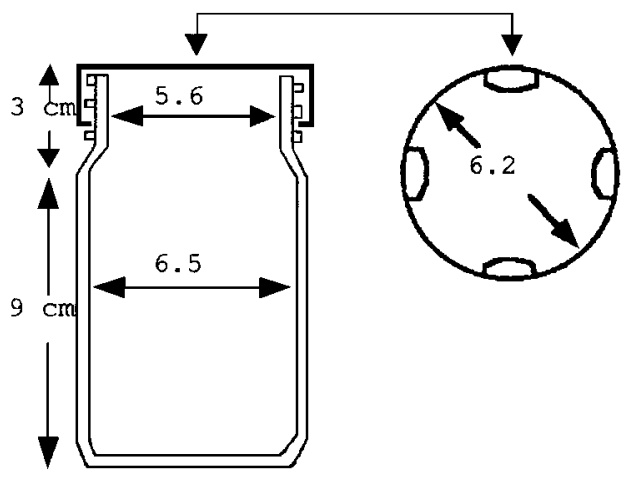

B

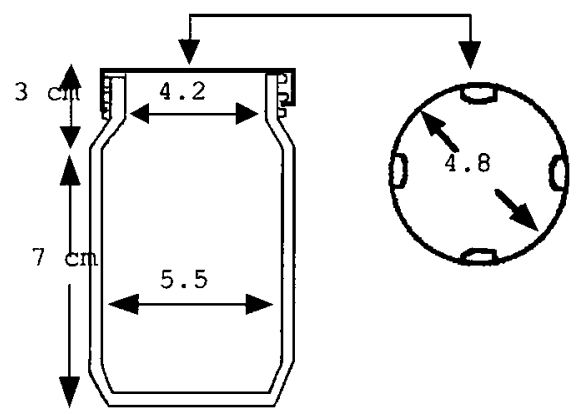

C

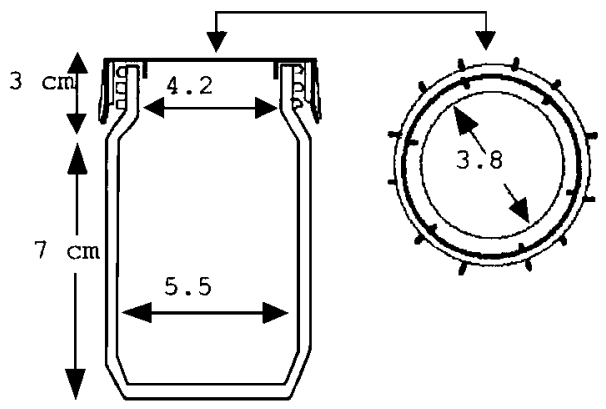

D

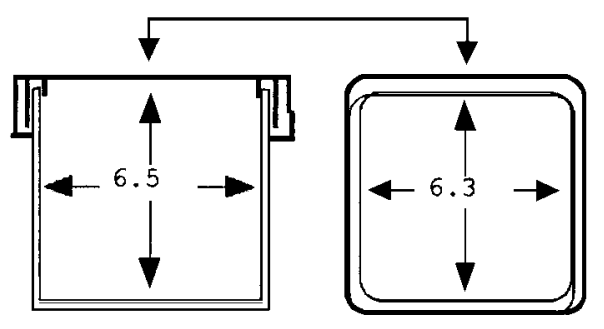

FIG. 1. Lateral views of the culture vessels fitted with their respective caps and frontal views of each cap showing the closing system. Size of each component is indicated in $\mathrm{cm}$. $A$, Glass jam jars, $370 \mathrm{ml}$ in volume, closed with metal steel caps. $B$, Glass baby-food jars, $200 \mathrm{ml}$ in volume, closed with metal steel caps. $C$, Glass baby-food jars, $200 \mathrm{ml}$ in volume, closed with polypropylene Magenta ${ }^{\mathrm{TM}} \mathrm{B}-\mathrm{caps}$. $D$, Magenta ${ }^{\mathrm{TM}} \mathrm{GA} 7$ culture vessels in polycarbonate, $275 \mathrm{ml}$ in volume, with polypropylene covers.

TABLE 1

MEDIUM VOLUME, NUMBER OF EXPLANTS CULTURED IN EACH CULTURE VESSEL, AMOUNT OF MEDIUM PER EXPLANT, AND RELATIONSHIP BETWEEN MEDIUM AND VESSEL VOLUME ASSAYED

\begin{tabular}{lccc}
\hline Vessel closure & $\begin{array}{c}\text { Jam jar, } \\
\text { metal cap }\end{array}$ & $\begin{array}{c}\text { Baby-food jar, } \\
\text { metal cap }\end{array}$ & $\begin{array}{c}\text { Magenta } \\
\text { GA7 }\end{array}$ \\
\hline$V_{\text {medium }}(\mathrm{ml})$ & 25 & 15 & 20 \\
Explants per vessel & 5 & 3 & 5 \\
$V_{\text {medium per explant }(\mathrm{ml})} / V_{\text {vessel }}$ & 5 & 5 & 5 \\
$V_{\text {medium }}$ & 0.07 & 0.07 & 5 \\
\hline
\end{tabular}

in the four culture vessels described in Fig. 1. The $\mathrm{pH}$ of the medium was adjusted to 5.7 before the addition of $0.7 \%(\mathrm{w} / \mathrm{v})$ agar, and autoclaved for $20 \mathrm{~min}$ at $120^{\circ} \mathrm{C}$ and $100 \mathrm{kPa}$. The total amount of medium and the number of explants cultured in each of the culture vessels (Table 1) were dependent on the total vessel volume. So, the relation between medium volume and vessel volume was 0.07 in all the types of vessel and the amount of medium per explant was always $5 \mathrm{ml}$, as summarized in Table 1 .

Cultures were incubated in a growth room at $25 \pm 2{ }^{\circ} \mathrm{C}$, and $16 \mathrm{~h}$ photoperiod provided by fluorescent Phillips TLD Standard lamps (photosynthetic photon flux desity, PPFD $=40 \mu \mathrm{mol} \mathrm{m}^{-2} \mathrm{~s}^{-1}$ ). Environmental characterization of culture vessels was made in vessels without explants maintained in these same conditions.

After $30 \mathrm{~d}$ in culture, explants were classified according to Fal et al.
(1999) as: normal, when shoots and leaves showed no anomaly; hyperhydric, when shoots or leaves had a fragile and glassy appearance; and mixed, when hyperhydric and normal shoots/leaves were present on the same explant. The percentages of normal, mixed, and hyperhydric explants were calculated from all the explants cultured in five of each vessel type (15 explants from baby-food jars, 20 explants from Magenta GA7 culture vessels, and 25 explants from jam jars). The number and length of the normal shoots produced per explant and the multiplication coefficient (number of normal nodal segments per explant) were also recorded from these explants and their mean and standard error calculated. The experiment was repeated twice.

PPFD was measured inside and outside the empty vessels with a radiometric sensor connected to a Delta-T MV2 microvoltimetric integrator. The percentage of PPFD inside the vessel with regard to the external PPFD 
TABLE 2

MEDIUM DESICCATION EXPRESSED AS GRAMS OF WATER LOST AFTER $30 \mathrm{~d}$ IN THE GROWTH ROOM AND RATE OF AIR EXCHANGE (E) IN FOUR TYPES OF CULTURE VESSEL

\begin{tabular}{lcccc}
\hline Vessel closure & $\begin{array}{c}\text { Jam jar, } \\
\text { metal cap }\end{array}$ & $\begin{array}{c}\text { Baby-food jar, } \\
\text { metal cap }\end{array}$ & $\begin{array}{c}\text { Baby-food jar, } \\
\text { Magenta B-cap }\end{array}$ & $\begin{array}{c}\text { Magenta } \\
\text { GA7 }\end{array}$ \\
\hline $\begin{array}{l}\text { Desiccation }(\mathrm{g}) \\
E\left(\mathrm{~h}^{-1}\right)\end{array}$ & $2.8 \pm 1.4 \mathrm{~b}$ & $3.4 \pm 0.4 \mathrm{~b}$ & $3.2 \pm 0.2 \mathrm{~b}$ & $10.4 \pm 0.8 \mathrm{a}$ \\
\hline
\end{tabular}

Means $\pm \mathrm{SE}$ are followed by different letters in the same row when differences between them were significant (Mann-Whitney test, $\alpha=0.05 ;, n=10)$.

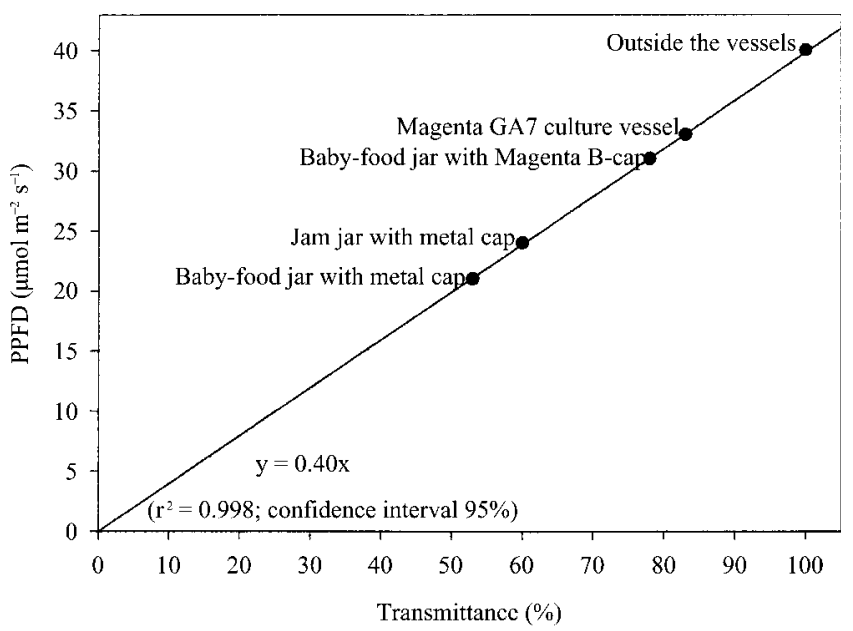

FIG. 2. Linear regression-fitting data of photosynthetic photon flux density inside culture vessels (PPFD) versus its light transmittance. Each point on the line corresponds to a type of culture vessel (indicated on the left of each value).

value (measured on the culture shelf) was considered the transmittance $(T)$ of each type of vessel.

The temperature and the relative humidity were measured inside the vessels as described previously (Majada et al., 1997), with a probe connected to a transmitter able to operate at high humidity (358 RHSolomat, Paris, France). The desiccation of the medium in each type of vessel, filled with medium (Table 2) but without explants, was calculated as the grams of water lost after $30 \mathrm{~d}$ in the growth chamber.

The number of air exchanges in the culture vessel ( $E$ : number of exchanges per h) was calculated according to Fujiwara and Kozai (1995) but using ethylene as the tracer gas. Ethylene was introduced in each vessel to reach a concentration of $0.22 \mu M$. Vessels were maintained for $2 \mathrm{~h}$ in the growth chamber. Then, aliquots of $1 \mathrm{ml}$ were taken from the atmosphere in the vessel and injected in a Perkin-Elmer Mod. 8310 gas chromatograph equipped with a Porapack $\mathrm{N}$ column $(50-60$ mesh, $2.5 \mathrm{~m} \times 3.2 \mathrm{~mm})$. Ethylene analysis was performed isothermally at $90^{\circ} \mathrm{C}$. The temperatures of the injector and the ionization detector were 110 and $120^{\circ} \mathrm{C}$, respectively, and $\mathrm{N}_{2}$ was used as carrier gas $\left(30 \mathrm{ml} \mathrm{min}^{-1}\right)$.

Samples for environmental variables were taken from ten vessels of each type, and the experiment was repeated twice.

Data were analyzed using the SPSS/PC $+{ }^{\mathrm{TM}}$ Statistical Package for IBM PC version 3.0 (SPSS Inc., Chicago). Regression analysis was performed for data of PPFD inside the vessels versus its light transmittance. Hyperhydricity data were analyzed as a qualitative variable by a cross-tab and chi-square test. Quantitative data of the rest of variables did not conform to the requirements for a parametric test. So, in all these cases the nonparametric Mann-Whitney test was used to test differences between culture vessels. All the hypotheses were tested at a significance level of 0.05 .

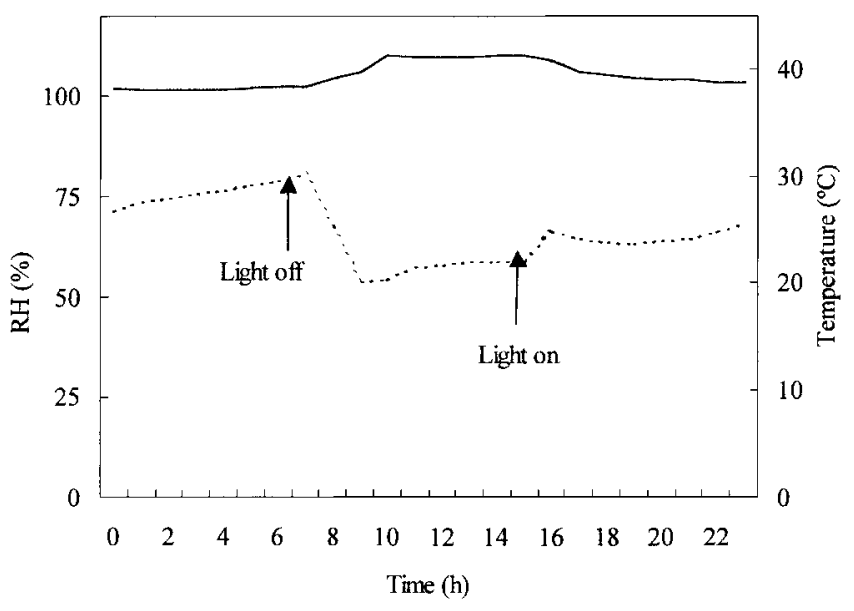

Relative humidity $(\%) \cdots \cdots$. Temperature $\left({ }^{\circ} \mathrm{C}\right)$

FIG. 3. Relative humidity $(\mathrm{RH})$ and temperature over a 24 -h period inside a culture vessel incubated in a growth room at $25^{\circ} \mathrm{C}$ and $16 \mathrm{~h}$ photoperiod.

\section{Results and Discussion}

Environmental characteristics inside the four types of culture vessels (Table 2; Figs. 2 and 3) were the result of both growth room conditions and properties of the culture vessel, as has been stated by other authors (Tricoli, 1983; Kozai et al., 1986, 1992).

Our results demonstrated two facts often overlooked in tissue culture. Light inside the culture vessel depends on the culture vessel and is different from the culture shelf (Fig. 2). Moreover, gas exchange can vary among different types of culture vessels, even when their closures seemed to be tight (Table 2).

PPFD inside the vessel was a linear function of the light transmittance of the vessel material (Fig. 2). This transmittance, and consequently PPFD, was higher in vessels closed with polypropylene than with metal caps, in agreement with Kozai et al. (1992) who reported that light inside the culture vessels depends mainly on the cap material as lamps are usually, as in our case, sited over the culture vessels. Moreover, the quality of the light transmitted by different materials could also be different inside the vessels, but no data were available in this sense, as the measuring device evaluates the total spectrum for photosynthesis without discerning wavelengths.

The PPFD measured in the vessels was not sufficient for photoautotrophic growth of explants (Fujiwara et al., 1987; Kubota 
TABLE 3

PERCENTAGES OF NORMAL-MIXED-HYPERHYDRIC EXPLANTS OF SEVERAL CULTIVARS OF DIANTHUS CARYOPHYLLUS CULTURED IN FOUR TYPES OF VESSEL

\begin{tabular}{lccc}
\hline Vessel closure & $\begin{array}{c}\text { Jam jar, } \\
\text { metal cap }\end{array}$ & $\begin{array}{c}\text { Baby-food jar, } \\
\text { metal cap }\end{array}$ & $\begin{array}{c}\text { Baby-food jar, } \\
\text { Magenta B-cap }\end{array}$ \\
\hline cv. Scania & $100-0-0$ a & $67-33-0$ a & $83-17-0$ a \\
cv. White Sim & $86-7-7$ a & $89-11-0$ a & $75-8-17$ a \\
cv. Angeline & $75-0-25$ a & $89-11-0$ a & $87-13-0$ a \\
cv. Pink Calypso & $0-0-100 \mathrm{~b}$ & $94-0-6$ a & $100-0-0$ a \\
\hline
\end{tabular}

Different letters in the same row indicate significant differences in the external appearance of explants (chi-square test; $\alpha=0.05 ; n=25$ explants from jam jars, 15 explants from baby-food jars, 20 explants from Magenta GA7).

and Kozai, 1990). So, it probably did not produce any effect on the growth of the cultures because of these heterotrophic conditions. Other possible photomorphogenic effects (i.e. on leaf size) also were not observed. However, differences in transmittance, such as those measured in our case (Fig. 2), could be very important when photoautotrophy of cultures needs to be promoted and/or higher PPFD values are necessary during culture.

The flux of a gas between the internal and external atmosphere of a vessel follows Fick's 1st and 2nd Law (Armstrong, 1979). Therefore, for a gas in particular, the flux is a function of the difference in concentration between inside and outside the vessel, its diffusion coefficient (when the vessel allows diffusion) that depends on the vessel composition, the surface through which diffusion takes place, and the diffusion pathway length. In our case we can assume that the difference in ethylene concentration between inside and outside was the same for the four types of culture vessels. Glass and steel are impermeable to gases. Nevertheless, there is some diffusion through the plastics, although it is difficult to estimate (Jackson et al., 1987). Significantly higher desiccation and $E$ values obtained in Magenta GA7 culture vessels (Table 2) indicated that this possibility should not be neglected.

Several in vitro culture vessels exhibited higher gas exchange (Kozai et al., 1986) and desiccation (Tricoli, 1983) when plastic caps were used instead of metal caps. However, in our case there was no difference between baby-food jars closed with steel or with polypropylene Magenta B-caps (Table 2). A possible explanation is poor adjustment of the metal cap on the rim of the vessel. So, the diffusion pathway length in metal caps that closed poorly was similar to that of polypropylene Magenta B-caps in which gas exchange occurred through the fitting between vessel and cap and also through the plastic.

The desiccation of the culture medium depended on water vapor diffusion outside the vessels. Therefore, $E$ (air exchange) and desiccation trends (Table 2) were similar, but they were not related by a simple equation as in the case of the transmittance and PPFD. The rate of water vapor exchange could be different from $E$ because of the selective gas permeability of plastics (Demeester et al., 1995). In particular, in our case results indicated that the polycarbonate vessel Magenta GA7 was more permeable to water vapor than to ethylene. Moreover, desiccation also depends on the rate of evaporation of the substrate and the rate of condensation of the evaporated water which are related to the temperature and humidity gradients inside the culture vessel.

Gradients inside the culture vessel could not be measured directly because our system only allowed measurement of temperature and relative humidity at a single point inside the culture vessel. However, gradient formation in the vessels seems very likely since changes in inner temperature related to the light period were shown over $24 \mathrm{~h}$ (Fig. 3). This daily cycle was similar in the four types of culture vessels and was also described by other authors (Kozai et al., 1992). The atmosphere was near water vapor saturation all day, and the temperature inside the culture vessel tended to increase during the light period and decrease in the dark period, promoting water condensation and over-saturation in the in vitro atmosphere (Fig. 3).

Hyperhydricity induced by lack of ventilation is described for several in vitro-cultured plants (McCown and Sellmer, 1987; Smith and McClelland, 1991; Debergh et al., 1992) and, particularly, in other D. caryophyllus cultivars in our previous reports (Majada et al., 1997, 2000; Fal et al., 1999). However, total hyperhydricity was induced only in 'Pink Calypso' explants cultured in jam jars with metal caps (the lowest $E$ and desiccation), but not in the other cultivars (Table 3). These differences between cultivars could be explained by genetic factors affecting sensitivity to hyperhydricity when plants are exposed to environmental factors involved in the induction of this anomaly.

Comparing results of $E$ in the culture vessels (Table 2) and hyperhydricity of 'Pink Calypso' (Table 3) we can see that significant differences with other vessels were only evident for the jam jars with metal caps in both cases. This parallelism could support the relationship between $\mathrm{E}$ in the culture vessel and hyperhydricity in this sensitive cultivar.

The influence of the type of vessel on the number of normal shoots and their length seemed to be exclusive, in the sense that it did not affect both variables at the same time (Fig. 4). The type of vessel had a significant effect $(P>0.95)$ on the number of normal shoots of 'Scania,' 'White Sim,' and 'Pink Calypso,' but not on their length (Fig. 4). The best shoot production from these cultivars was in culture vessels with an intermediate value of $E$ and desiccation (Fig. 4; Table 2). In contrast, culture vessel type significantly affected the shoot length of 'Angeline' but not the number of normal shoots (Fig. 4). In this case, a negative effect of $E$ and desiccation on the shoot elongation of this cultivar was evident, as shorter shoots were obtained as $E$ and desiccation increased (Fig. 4; Table 2).

The vessel type influenced growth of 'Scania' and 'White Sim' shoots, but their multiplication coefficient was not affected (Fig. 4). However, the multiplication coefficient of 'Angeline' and 'Pink Calypso' was affected by the vessel type, showing the highest 


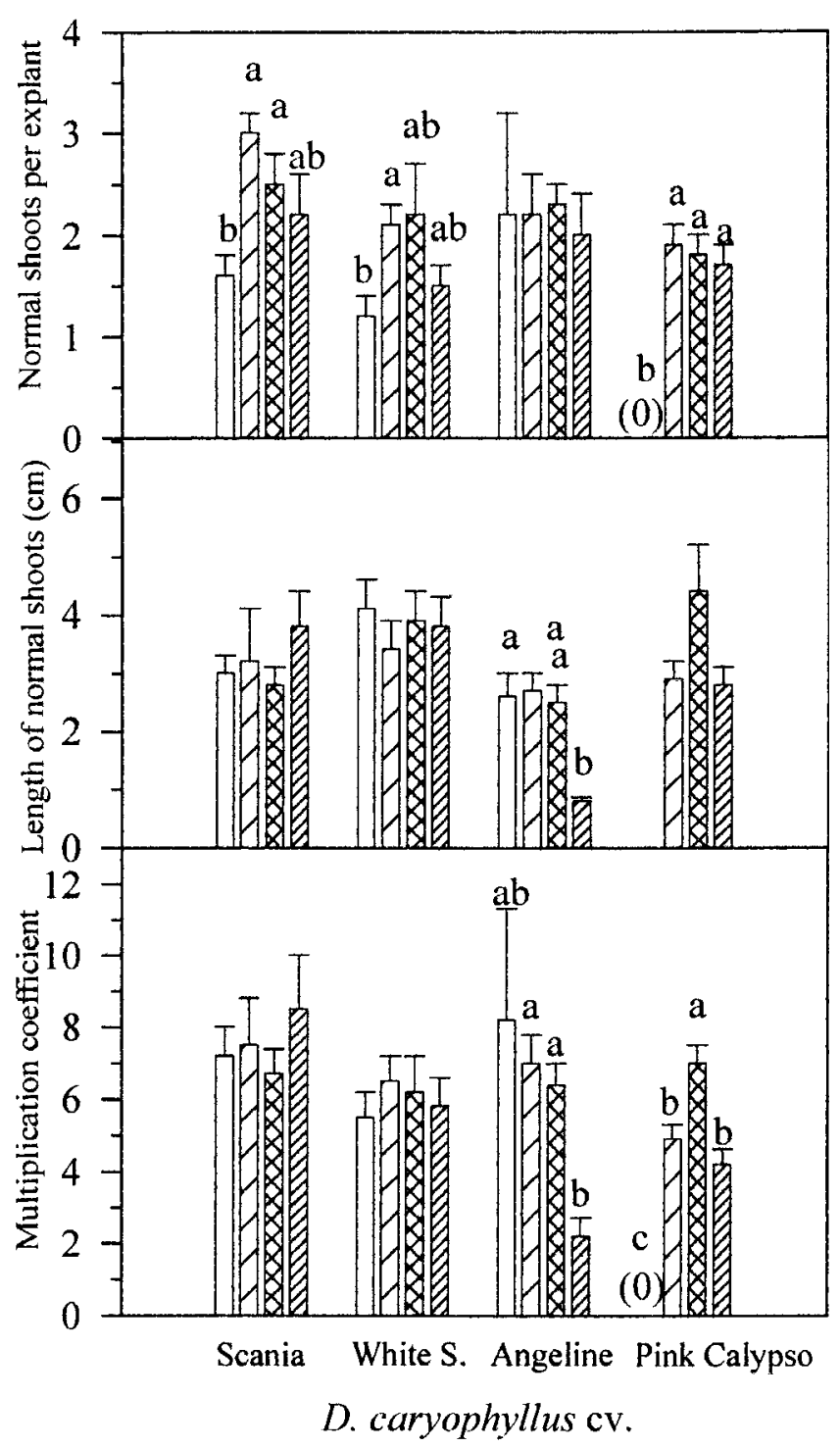

Vessel closure:

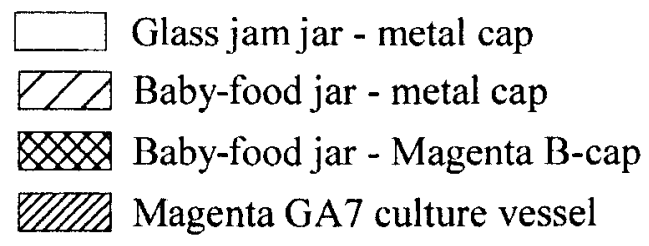

FIG. 4. Number of normal shoots, length of the shoots, and multiplication coefficient (number of normal nodal segments produced per explant) obtained for cultivars of $D$. caryophyllus cultured in four types of culture vessel. Values are means $\pm \mathrm{SE}$ (vertical bars). For each cultivar, different letters on the bars indicate significant differences between vessels; no letters are on the bars when differences between vessels were not significant (Mann-Whitney test, $\alpha=0.05$ ). (0): mean value $=0$.

multiplication coefficient when they were cultured in vessels with intermediate values of $E$ and/or desiccation in the range described in this paper (Table 2). A certain equilibrium between the gas exchange and the desiccation in the culture vessel seemed to be necessary for good multiplication. Other reports also support the hypothesis that when the ventilation is increased the desiccation could become excessive (McCown and Sellmer, 1987; Sallanon and Maziere, 1992), promoting growth inhibition (Walker et al., 1989).

Sallanon and Maziere (1992) gave two possible explanations for the growth inhibition observed in ventilated vessels: (1) If ventilation is high, stomata are always open and water loss will be high, especially in light. Moreover, in the dark period there is no possibility of compensating the water lost, as relative humidity is not high enough. (2) Evaporation of the culture medium induces water stress at the base of the plantlet and so it grows less vigorously. Explanation (1) seemed to be more suitable in our case, because desiccation of the culture medium was measured in the culture vessels. Moreover, all vessels at all time periods showed a relative humidity over $100 \%$ (Fig. 3).

Vessels/closure configurations exert direct and indirect control over the physical environmental factors in vitro. As medium becomes modified over time of culture, several changes occur in the vapor pressure deficit in the vessel (Sallanon and Coudret, 1990). Differences in $E$ between vessels will determine not only the accumulation of gases, but also other characteristics such as relative humidity, agar concentration, nutrients and water availability (Dencso, 1987; Gaspar et al., 1987; Ziv, 1991; Debergh et al., 1992).

Genetic factors determine the sensitivity of plant material to environmental factors and their final effects on hyperhydricity, necrosis or, in general, growth and morphogenesis in vitro. However, it is evident that the interaction between inner and outer environments, vessels, supports and closures, their design and materials, regulate the degree to which physicochemical factors in the growth room impact on the microenvironment and affect, finally, the success of plant micropropagation. In this sense our results indicate that even in non-ventilated systems, the rate of gas exchange in the culture vessel is one of the most important considerations in optimizing micropropagation.

\section{ACKNowledgments}

Research support was provided by grants from the Spanish Ministerio de Educacion y Cultura (MEC) and from the Fundacion del Principado de Asturias para el Fomento de la Investigación Científica y Tecnológica (FICYT). Sincere thanks go also to Rachel Huijsers for reading the manuscript and for her helpful suggestions for correcting the English grammar and orthography.

\section{REFERENCES}

Armstrong, W. Aeration in higher plants. Adv. Bot. Res. 7:225-332; 1979. Casares, A.; Estrada, O.; Astorga, R.; Rodríguez, R. Aplicaciones del cultivo de tejidos I. Saneamiento del clavel mediante cultivo de meristemos. Revista de la Sociedad Española de Horticultura no. 6882; 1987: 8-10.

De Proft, M. P.; Maene, L. J.; Debergh, P. C. Carbon dioxide and ethylene evolution in the culture atmosphere of Magnolia cultured in vitro. Physiol. Plant. 65:375-379; 1985.

Debergh, P.; Aitken-Christie, J.; Cohen, D.; Grout, B.; von Arnold, S.; Zimmerman, R.; Ziv, M. Reconsideration of the term 'vitrification' as used in micropropagation. Plant Cell Tiss. Organ Cult. 30:135-140; 1992.

Demeester, J. J.; Matthijs, D. J.; Pascat, B.; Debergh, P. C. Toward a controllable headspace composition - growth, development, and headspace of a micropropagated Prunus rootstock in different containers. In Vitro Cell. Dev. Biol. Plant 31:105-112; 1995. 
Dencso, I. Factors influencing vitrification of carnation and conifers. Acta Hort. 212:169-175; 1987.

Drew, A. P.; Kavanagh, K. L.; Maynard, C. A. Comparative growth of micropropagated Prunus serotina plantlets and seedlings in different containers. In: Valentine, F. A., ed. Forest and crop biotechnology. Progress and prospects. New York: Springer Verlag; 1988:99-111.

Fal, M. A.; Majada, J. P.; González, A.; Sánchez Tamés, R. Difference between Dianthus caryophyllus L. cultivars in in vitro growth and morphogenesis are related to their ethylene production. Plant Growth Regul. 27:131-136; 1999.

Fujiwara, K.; Kozai, T. Physical microenvironment and its effects. In: Aitken-Christie, J.; Kozai, T.; Smith, M. A. L., eds. Automation and environmental control in plant tissue culture. Dordrecht: Kluwer Academic Publishers; 1995:319-336.

Fujiwara, K.; Kozai, T.; Watanabe, I. Fundamental studies on environments in plant tissue culture vessels. (3) Measurements of carbon dioxide gas concentration in closed vessels containing tissue cultured plantlets and estimates of net photosynthetic rates of the plantlets. J. Agric. Met. 43(1): 21-30; 1987.

Gaspar, Th.; Kevers, C.; Debergh, P.; Maene, L.; Paques, M.; Boxus, Ph. Vitrification: morphological, physiological, and ecological aspects. In: Bonga, J. M.; Durzan, D. J., eds. Cell and tissue culture in forestry, vol. 1. Dordrecht: Martinus Nijhoff Publishers; 1987:152-160.

Jackson, M. B.; Abbott, A. J.; Belcher, A. R.; Hall, K. C. Gas exchange in plant tissue cultures. In: Jackson, M. B.; Mantell, S. H.; Blake, J., eds. Advances in the chemical manipulation of plant tissue cultures, London: Proc. Meet. British Plant Growth Regulator Group, Monograph 16; 1987:57-71.

Kozai, T.; Fujiwara, K.; Hayashi, M.; Aitken-Christie, J. The in vitro environment and its control in micropropagation. In: Kurata, K. Kozai, T., eds. Transplant production systems. Dordrecht: Kluwer Academic Publishers; 1992:247-282.

Kozai, T.; Fujiwara, K.; Watanabe, I. Fundamental studies on environments in plant tissue culture vessels. (2) Effects of stoppers and vessels on gas exchange rates between inside and outside of vessels closed with stoppers. J. Agric. Met. 42(2): 119-127; 1986.

Kubota, C.; Kozai, T. Effects of forced/natural ventilation on photoautotrophic growth of potato (Solanum tuberosum L.) plug plantlets in vitro. 7th Int. Congress on Plant Tissue and Cell Culture, Amsterdam, June 24-29. Topic code A3, no. 058/072R; 1990.

Majada, J. P.; Fal, M. A.; Sánchez Tamés, R. The effect of ventilation rate on proliferation and hyperhydricity of Dianthus caryophyllus L. In Vitro Cell. Dev. Biol. Plant 33:62-69; 1997.

Majada, J. P.; Tadeo, F.; Fal, M. A.; Sánchez Tamés, R. Impact of culture vessel ventilation on the anatomy and morphology of micropropagated carnation. Plant Cell Tiss. Organ Cult. 63:207-214; 2000.

McClelland, M. T.; Smith, M. A. L. Vessel type, closure, and explant orientation influence in vitro performance of five woody species. HortScience 25(7): 797-800; 1990.

McCown, B. H.; Sellmer, J. C. General media and vessels suitable for woody plants culture. In: Bonga, J. M.; Durzan, D. J., eds. Cell and tissue culture in forestry, vol. 1. Dordrecht: Martinus Nijhoff Publishers; 1987:4-17.

Murashige, T.; Skoog, F. A revised medium for rapid growth and bioassays with tobacco tissue cultures. Physiol. Plant 15:473-497; 1962.

Sallanon, H.; Coudret, A. Flux d'eau entre vitroplants et atmosphère en micropropagation. CR Acad. Sci. Paris 310, Serie III:607-613; 1990.

Sallanon, H.; Maziere, Y. Influence of growth room and vessel humidity on the in vitro development of rose plants. Plant Cell Tiss. Organ Cult. 30:121-125; 1992.

Smith, M. A. L.; McClelland, M. T. Gauging the influence of in vitro conditions on in vivo quality and performance of woody plants. In Vitro Cell. Dev. Biol. Plant 27:52-56; 1991.

Tricoli, D. M. In vitro propagation of Prunus serotina Ehrh., MS thesis, State University of New York, College of Environmental Science and Forestry, Syracuse, NY; 1983:1-94.

Walker, P. N.; Heuser, C. W.; Heinemann, P. H. Micropropagation: effects of ventilation and carbon dioxide level on Rhododendron 'P.J.M.' Trans. ASAE 32(1): 348-352; 1989.

Ziv, M. In vitro hardening and acclimatization of tissue culture plants. In: Withers, L. A.; Alderson, P. G., eds. Plant tissue culture and its agricultural applications. London: Butterworths; 1986:187-196.

Ziv, M. Vitrification: morphological and physiological disorders of in vitro plants. In: Debergh, P. C.; Zimmerman, R. H., eds. Micropropagation. Dordrecht: Kluwer Academic Publishers; 1991:45-69. 